\title{
Primož Jurko
}

Department of translation

Faculty of Arts

University of Ljubljana

\section{Divergent Polysemy: \\ The Case of Slovene namreč vs. English namely}

Summary

Divergent polysemy is a formidable translation problem, especially in L1-L2 translation. In the paper the case of the Slovene-English pair of items namrec and namely was used to illustrate the most frequent polysemy-triggered translation errors and their corrections. The hypothesis of full transferability of semantic structures from L1 into L2 was identified as one of the sources of errors. Since dictionaries turned out to be of limited use, electronic corpora were consulted to shed more light on the matter; they revealed huge differences in patterns of use between the two terms, which in turn determined the proposed plan of action. Bilingual lexicography, EFL teaching and translator education are key factors in improving the current situation.

Keywords: divergent polysemy, contrastive lexicology, bilingual lexicography, L1-L2 encoding translation, corpus linguistics.

\section{Divergentna polisemija: zakaj ni vsak slovenski namreč v angleškem prevodu namely.}

\section{Povzetek}

Slovensko-angleški par leksemov namreč-namely je služil za ponazoritev težav pri prevajanju večpomenskih enot, $s$ posebnim poudarkom na divergentni polisemiji. $\mathrm{Na}$ tem primeru so prikazane najpogostejše napake študentov prevajanja in prevajalcev, ki v ciljnem jeziku pogosto zmotno predpostavijo enako pomensko strukturo leksema, kot jo ima ustreznica v izvornem jeziku. Prikazane so omejene možnosti slovarjev, z analizo elektronskih korpusov pa smo odkrili velike razlike v pogostosti izrazov v obeh jezikih, kar je bilo odločilno pri določanju strategije za nadaljnje delo. K preseganju stanja lahko največ pripomorejo dvojezično slovaropisje, poučevanje angleščine in izobraževanje prevajalcev.

Ključne besede: divergentna polisemija, protistavno besedoslovje, dvojezično slovaropisje, prevajanje $\mathrm{v}$ nematerni jezik, korpusno jezikoslovje. 


\section{Divergent Polysemy: \\ The Case of Slovene namreč vs. English namely}

\section{Introduction}

The present paper was prompted by the fact that the Slovene adverb / conjunction namrec is very often almost automatically translated into English as namely. While in some (surprisingly rare) instances this produces a good translation, such cases are vastly outnumbered by translations where the choice of namely is un-idiomatic at best and simply wrong at worst. In my experience, and as shall be shown, this tricky (yet entirely avoidable) issue is one of the most predictable Slovene-into-English translation errors.

The reasons for this situation are no doubt complex, as in most cases of L1 - L2 translation errors; in spite of this complexity, here we will focus only on those that fall into one of the two groups:
a) (unjustified) relying on Slovene-English dictionaries (the Slovene-English part of Zaranšek (2006), Grad and Leeming (1990), and
b) false assumption of full transferability of meaning structures of L1 and L2 items. These two reasons are arguably accountable for most, if not all, errors of the namreč-namely type.

\section{Error zone}

\subsection{What is right...}

The following examples were all taken from texts translated by Slovene students of translation in their 3rd year of studies. Consider instances such as:

(1) Le majhna skupina držav, namreč Litva, Estonija in Slovenija, se predlogu ni pridružila. Except for a few countries, namely Lithuania, Estonia and Slovenia, all others agreed with the proposal.

(2) V predgovoru je omenil dva poglavitna vira navdiha, namreč svojo družino in ljubezen do narave.

He mentioned two sources of inspiration in the preface, namely his family and the love of nature.

In the above examples the situation is relatively clear-cut: both namrec and namely are used with reference to a previously-mentioned entity. They are both used to introduce additional information about that entity, providing the reader with more specific, even name-revealing information. 


\section{$2.2 \ldots$ and what is wrong?}

On the other hand, the following examples look deceivingly similar to those above:

(3) Od poglavja do poglavja nam Ihan našteva, kako stres prepoznamo, skriva se namreč v veliki zbirki znamenj, in kako se ga ubranimo...

...stress is ${ }^{*}$ namely disguised in many ways...

(4) Prejšnjega direktorja Alberta Barbero so namreč po politični liniji odstavili, namesto njega pa nastavili Moritza de Hadelna.

The previous director Alberto Barbera has * namely been ousted for political reasons, and Moritz de Hadeln came to fill the slot.

(5) Ob avtocestah na avstrijskem Koroškem so namreč začeli zamenjavati prometne napise ...

* Namely, road signs in the Austrian Carinthia are being replaced...

(6) Gre namreč za domišljen album, ki ...

It is ${ }^{*}$ namely a rather well thought-out album, which...

(7) Od takrat bodo namreč začeli veljati enotni "potni listi”, v katerih bo ... Uniform pet passports will * namely be introduced at that time...

(8) Oba koncertna prostora sta namreč dopuščala bolj osebno doživljanje izvajane... Both concert venues * namely enabled the auditorium to experience the music...

(9) Festival ima namreč poleg kulturne tudi nalogo spodbujanja sožitja ... Aside from its cultural role the festival has ${ }^{*}$ namely also ...

(10) Pri slovenskem jeziku namreč zadošča pisna naloga ... A written assignment will * namely be enough...

All translations in instances (4)-(10) are wrong. They were based on the assumption that the namrec-namely equivalence is genuine in all texts and at all times, which is simply not true. The core of the problem at hand is then to find out just what it is that actually made the translator choose the wrong word and how to stop him/her from doing the same again and again.

\section{Dictionary situation}

\subsection{Encoding dictionaries}

The basic reference material in any L1-L2 translation is sure to be the bilingual dictionary for encoding purposes. In our analysis we will take a look at how the largest Slovene-English dictionary (Grad and Leeming 1990) and the most recent one (Zaranšek 2006) present data 
relevant to our topic. Although the underlying principle applied in both dictionaries differs greatly, we will not discuss this at any length. Rather, we will focus on how well the dictionaries do what they are supposed to do: lead the translator to an idiomatic lexical choice.

The entry in Grad and Leeming is:

namreč namely; that is to say; videlicet (krajšava: viz.); (= t.j., to je) to wit; in other words; nisem mogel govoriti z njim, bil je - bolan I could not speak to him, as (ali seeing that) he was ill; eden mojih sosedov, - neki X.Y., ... one or my neighbours, to wit, one X.Y., ...

And this is the entry in Zaranšek:

namreč 1. (za pojasnjevanje) namely, that is to say. 2. (za utemeljevanje) in fact: izumitelj namrec labko potem patent proda - in fact, the inventor can sell his patent later on

Namely is the first option listed in both dictionaries, so its popularity among budding translators should come as no surprise. However, if they inspected more closely, they might find it strange if not worrying that none of the examples used in Grad's or Zaranšek's dictionary is translated by namely. The polysemous nature of namreč is nevertheless far better represented in Zaranšek's entry, which hints at the complexity behind the seemingly straighforward term. The second equivalent has its limitations, as pointed out in (23), but is still a valid choice in many contexts.

It is a matter of fact that skilled student translators do not need to consult the dictionary to fulfil most of their translation tasks. Indeed, if they are familiar with the subject matter of the text, they often already know all the words. However, there will always be cases where the translator is simply in the dark as to how a given lexical item might be rendered in the target language. A reliable encoding dictionary is a good starting point in such instances - but it is only that: a starting point, from which translators should then explore various possibilities of capturing the message of the source text. Thus, before using a translation equivalent for the first time, they are very likely to consult several monolingual dictionaries of the target language, check available language corpora, study parallel texts, and / or even consult colleagues with more experience in the lexical field at hand. When the target language is English, they have one more highly reliable source at their disposal: the EFL dictionary. Let us take a look at some of them.

\subsection{EFL dictionaries}

Five of the most popular and, by wide consensus best EFL dictionaries - namely the Longman Exams Coach (LEC) (Summers 2006), Macmillan English Dictionary (MED) (Rundell 2002), Oxford Advanced Learner's Dictionary (OALD) (Wehmeier 2005), Collins COBUILD Advanced Learner's English Dictionary (COBUILD) (Sinclair 2006) and the Cambridge Advanced Learner's Dictionary (CALD) (Walter 2005) -were selected: 
(13) LEC: used when saying the names of the people or things you are referring to: Three students were mentioned, namely John, Sarah and Sylvia.

(14) MED: used for introducing more detailed information about a subject you are discussing: Some groups, namely students and pensioners, will benefit from the new tax.

(15) OALD: used to introduce more exact and detailed information about sth that you have just mentioned:

We need to concentrate on our target audience, namely women aged between 20 and 30.

(16) COBUILD: You use namely to introduce detailed information about the subject you are discussing, or a particular aspect of it.

One group of people seems to be forgotten, namely pensioners...

They were hardly aware of the challenge facing them, namely, to re-establish prosperity.

(17) CALD: used when you want to give more detail or be more exact about something you have just said.

We need to get more teachers into the classrooms where they're most needed, namely in high poverty areas.

I learned an important lesson when I lost my job, namely that nothing is a hundred percent guaranteed.

Both definitions and examples of use in the above entries clearly show that whenever additional information (usually more precise or specific) about something or somebody is given, the use of namely corresponds to that of the Slovene namreč.

\subsection{Desktop dictionaries}

Somehow expectedly, the desktop dictionaries is of little use if the translator needs to check the meaning of namely or how it is properly used: this kind of information is simply not needed by its target users, i.e. native speakers of English. Points in case are the definitions provided in Merriam-Webster's Collegiate Dictionary (MW) (Mish 2003) and the Collins English Dictionary Online (CEDO):

MW: namely: that is to say, to wit

CEDO: namely: that is to say

The entry is in both dictionaries given the same paraphrastic equivalent of that is to say, and MW added the now obsolete to wit, however the Slovene translator who turns to such dictionaries is given no clues as to what to do with namreč: translate it as namely or not?

In addition to the above two types of words that any translator has to deal with (i.e. those that s/he already knows and those that s/he has never heard nor used before), there is also a third 
kind of words: neither fully known nor entirely unknown. It would appear that namrec is one of these words; it seems so innocent and harmless (indeed students call it "easy") that most people will never bother looking the word up in a dictionary (and there are reasons for that, as will be argued); instead of doing so, they will follow their instinct and simply rely on namely. And even if they do look it up, chances are they will get it wrong anyway, as we have just seen. We may now take a look at what happens if one says no to dictionaries and relies on what is (believed to be) already known.

\section{Transferability assumption}

According to SSKJ (SAZU 1998), the principal lexicographic reference of contemporary Slovene, the semantic structure of namrec is twofold:

(20) 1. as an adverb it is used to introduce specific information about something that has just been mentioned, as in midva, namreč žena in jaz; starše obǐ̌če enkrat na leto, namreč na materin rojstni dan;

(21) 2. as a conjunction it is used to explain, justify or give reasons for what has just been mentioned, as in tekmovalcev je bilo malo, večina jih namreč služi vojaški rok; vseh se polašča nervoza: zdaj namreč gre za velike stvari / redko: avto imam v garaži. Namreč, ko sem ga pustil zunaj, so vlomili vanj.

When the Slovene translator approaches namreč with this polysemous structure embedded in his/her idiolect, it is easy to understand why s/he is tempted to translate both examples (20) and (21) with namely. However, as my attempts show, all those under (21) will invariably result in an error:

(22) There were few competitors, ${ }^{*}$ namely a lot of them are in the army. Everyone is getting nervous, ${ }^{*}$ namely there is a lot at stake now. I keep my car in the garage. ${ }^{*}$ Namely, when I left it outside once, it was broken in.

While Zaranšek's dictionary would lead to an arguably acceptable translation in the second example, the other two would hardly make any sense:

Everyone is getting nervous, in fact, there is a lot at stake now There were few competitors, ${ }^{*}$ in fact, a lot of them are in the army. I keep my car in the garage. ${ }^{*}$ In fact, when I left it outside once, it was broken in.

Apparently, the (21) meaning of namrec is not present in namely, which is definitely the main part of the problem. The translator is thus misled by his/her idea that the L2 item is an exact copy of the L1 item in terms of its meaning structure, which s/he then simply transfers into L2 - this is only one of the contrastive lexicological phenomena that fall in the category of divergent polysemy, which has been very insightfully discussed in Gabrovšek (2005, 120-5). However, 
there appears to be a basic difference between sets such as odvisnost vs. dependence or addiction, tovor vs. freight or cargo (ibid., 121) on the one hand, and namrec vs. namely on the other: one is of course the difference between full or lexical words and grammatical words; yet there appears to be something else. To find out what this might be let us take a look at how the two items are represented in their respective language corpora.

\section{Corpora situation: the British National Corpus vs. Fidaplus and Nova Beseda 5.1 Frequency of occurrence}

The 100 million word BNC recorded 2,145 occurrences of namely. A random selection of 10 hits follows:

(24) We do not wish to commit the mistake that Woolgar believes is widespread in social science: namely, of suggesting that the only knowledge which is not subject to the influence of contingent historical, cultural, and social processes is that which we ourselves have written.

They aim at instilling into the children what the Gikuyu call, namely, educating the children in the family and clan tradition.

It would appear his ideas ran along similar lines to Mignet's, namely to produce a simple, cheap, no-frills aeroplane in which every enthusiastic 'Mr Average' could take to the skies.

I now turn to the other dimension of culture within higher education; namely, higher education as a cultural experience for students.

He is also critical of UK policy that prohibits one form of vertical restraint, namely resale price maintenance, while taking a more relaxed view of other restraints.

In a few areas the proposed treatment will considerably undermine the main purpose of the forthcoming Financial Reporting Standard, namely to reflect the substance of transactions in assets or liabilities.

What you really want to know is what men always want to know about women, namely would she, if asked, and if not, why not.

But it does carry a corollary which is fundamental: namely, that for democracy to give in to terrorism is to undermine its own deepest foundation.

The House of Lords felt there was no justification for assessing one trustee, namely the resident trustee, as, for instance, he had no right or control over the income.

The role of the private practitioner has, however, been called into question in respect of two of the requirements of an advice agency discussed at the beginning of this chapter, namely the cost and availability of the service.

On the Slovene side the picture looks very different: in the 621 million word corpus FidaPLUS namreč occurs as many as 428,012 times, which makes it roughly 40 times more frequent than the English namely in the BNC. Let us take a look at 10 randomly selected hits: 
(25) Kot odlična novinarka je namreč znala povedati Američanom, da se v Iranu krepi večina, ki je vse drugačna, sodobnejša in strpnejša.

Kip svobode namreč izvirno sploh ni bil usojen za New York.

Najtežji položaj bo namreč nastopil prav v tem obdobju.

Vse drugo je boljše. e sicer je namreč položaj več kot alarmanten.

Avtor Komunističnega manifesta je bil namreč dopisnik konservativnega časnika

New York Tribune.

V tiskalnik sta namreč vgrajeni tehnologiji PhotoREt II in ColorSmart II.

Pa nas vedno izigrajo in pustijo na cedilu. Tisti namreč, ki so dolžni in ki tudi obljubijo, da...

Takrat se ljudje raje odstranijo, Weinstein je namreč znan kot najzlobnejši šef, kar si jih lahko zamislite.

Kemična sestava je namreč precej drugačna od padavinske vode.

Sam je namreč v njej vedno čutil tudi lirično noto.

The 40:1 ratio between the respective frequencies of namrec and namely is corroborated also by Nova beseda, a 202-milion-word corpus of Slovene: the number of hits of namrec is 152,487 in the whole corpus. Clearly, such discrepancy merits a somewhat more detailed treatment. In the next portion, parallel corpora of Slovene and English will be briefly consulted to show what happens to namreč and namely in the course of translation.

\subsection{Is namreč redundant?}

It may just as well be, based on the data obtained from parallel corpora (Evrokorpus, Elan, Trans). The difference between frequencies of namrec and namely, respectively, is huge; however, what is somewhat surprising is the fact, judging by the way it is translated into English in Slovene texts - by total omission - namreč very often appears to be devoid of meaning. Consider the following examples, where this is the case:

(26) Pretežno izvozno usmerjene dejavnosti v okviru predelovalnih dejavnosti so namreč lani proizvodnjo povečale za $6.5 \%$, preostale dejavnosti pa le za $0.6 \%$ ( gl. stran 22 ). Mainly export-oriented sectors within manufacturing increased their production by $6.5 \%$ last year, whilst other sectors recorded only $0.6 \%$ (see p. 22 ).

Usmeritev namreč posega v tisti socialni sloj, ki si ob sicer ugodnih pogojih za odkup družbenih stanovanj v procesu privatizacije.

This measure would affect social classes that could not afford to buy a state-owned flat in the period of privatisation.

Tako izmerjeni proizvodni stroški so se namreč v enakem obdobju povečali za $1.2 \%$. Production costs measured in this way increased by $1.2 \%$ in the same period.

Korelacija rangov indikatorjev DT in GKI 12 držav je namreč visoka (0.916. brez Finske 0.932 ). 
The correlation between the country risk and global competitiveness index indicators for the 12 countries is very high ( 0.916 . and 0.932 excluding Finland).

Izvoz blaga je namreč po izločitvi medvalutnih razmerij porasel za $13.2 \%$, uvoz blaga pa za $10.9 \%$, medtem_ko je bil izvoz blaga po tekočih USD v prvih petih mesecih v primerjavi z enakim obdobjem lani večji za $6.6 \%$, uvoz blaga pa za $4.6 \%$.

... inter-currency ratio changes had more influence on exports than imports and one can see that, after inter-currency ratio adjustments, the export of goods increased by $13.2 \%$ and the import of goods by $10.9 \%$. However, exports calculated in current US $\$$ rate increased by $6.6 \%$ and imports by $4.6 \%$ comparing the first five months this year to the same period last year.

Kaj malo bi namreč pomenilo zgolj državno varstvo pravic in svoboščin, če bi to ne bilo izraz volje in zahteve njenih državljanov There would be little weight in the mere protection by the state of rights and freedoms, if this was not an expression of the will and demands of its citizens.

V prvih nekaj letih naj bi se namreč na račun zadrževanja rasti plač in socialnih izdatkov omogočalo dodatno investiranje in prestrukturiranje, ki pa naj bi se... ... efforts made to compress wages and social expenditures will in the first years permit additional investment and restructuring expenditure to ease the transition process and sustain growth.

Poljski tržni delež je namreč v primerjavi s slovenskim do leta 1996 bistveno hitreje naraščal, kljub relativni rasti poljskega deleža stroškov dela $\mathrm{v}$...

Until 1996, Poland 's market share had been rising faster than Slovenia's despite Poland's relative growth in the share of labour costs in value added, and Hungary's share rose slower despite a fall in the share of labour costs in value added compared to Slovenia.

Zavlačevanje z izvedbo reform bi namreč upočasnilo gospodarsko rast, s tem pa tudi znižalo davčne prihode, izdatki za pokojnine pa bi še naprej ...

... social protection measures or to prevent a deterioration of the public accounts, if undue delays in the implementation of the above mentioned reforms should slow down the rate of growth of the economy and hence of the tax revenues, whilst the cost of pensions would continue to increase at its present high pace.

It seems hard to argue that the English texts in the above examples lack any information that is present in the Slovene originals, although, admittedly, these examples should be presented in their original context, as it is possible (although not very likely) that nuances of meaning contained in namreč were shifted to sentences preceding or following the one discussed. If namreč is in fact in Slovene predominantly used as a semantically empty word, this would account for the surprisingly high difference in the overall frequency compared to namely. Yet, intuitively, most 
Slovenes would argue that namrec does have a meaning and that it serves the purpose of making clear that what follows is only a further clarification of the facts stated earlier. On the other hand, such elements stressing clarification may be felt as a patronizing attitude of the speaker/author toward his/her audience/readers - why additionally explain the obvious? Such expressions or even a patronizing tone alone are not well received in any culture, to be sure, but are perhaps particularly painstakingly avoided in English, where patronizing almost equals rudeness. This might be seen as another factor that leads to the omission of patronizing elements and thus contributes to the tendency of translating namreč with nothing at all.

Random sampling of the corpora has revealed that in Slovene the predominant use of namrec is that of a discourse marker with loose anaphoric reference: in this function it may refer to any fact, circumstance and even complex situation mentioned earlier. According to our findings the (20) meaning of namreč, which can be translated into English as namely, accounts for less than 1 per cent of all occurrences; however, further and more extensive research of Slovene corpora is needed to corroborate these preliminary results.

\subsection{Not only a beginner's problem}

Another interesting fact arose from analyzing parallel corpora: even in Slovene-English translations which were done by highly skilled translators, the use of namely in the English translation is quite frequently incorrect, as in the following examples from the IJS-ELAN corpus:

(27) opredeljen kot zadnji, prav gotovo predstavlja pogoj in hkrati oporo prenovi, vprašanje povečanja absorbcijske moči sistema, ki jo dosegamo s pridobivanjem novih znanj in usposobljenosti je namreč odločujoče za vse nadaljnje transformacijske procese. Although the area is mentioned as the last one, there is no doubt that it represents the precondition, and at the same time support, of the modernisation. Namely, the issue of the increase of the absorption strength of the system gained by the acquisition of new knowledge and training is decisive for all further transformation processes.

naj bi namreč na vprašanje, kje so kritične točke ali razhajanja med nacionalnimi in “ evropskimi "standardi v institucionalem pogledu, organizaciji ali pravni ureditvi ter predvidela ukrepe za njihovo uskladitev.

Namely, it is supposed to answer the question as to where are the critical points or points of divergence...

Enostavna primerjava policijskih statistik namreč ne more pokazati kvalitativnih sprememb, saj je metodologija zajemanja podatkov prilagojena spremljanju konvencionalnega kriminala. Šele na podlagi

Namely, a simple comparison of police statistics cannot indicate qualitative modifications, since data selection methodology is adapted to the study of conventional crime. 
The preceding examples were translated by a team of professional translators, yet are in no way different from those of my students (cf. 2.2), in spite of the fact that the levels of acquired translation skills of the former and the latter differ greatly. What we are dealing with here is not a beginner's translation error, but clearly a danger facing the non-attentive translator at all times.

\subsection{The other way around}

An additional intriguing fact was provided by Evrokorpus: as it is designed to suggest a translation equivalent for any query entered, it was interesting to see that when the direction of translation was reversed, i.e. from English into Slovene, the suggested term for namely was in sicer. Here too, cases of questionable (if not wrong) "automatic" translation namely-namrec were found. In (28) the choice of in sicer placed immediately after the comma would lead to an arguably better Slovene rendering:

(28) restructuring and conversion have two main financial impacts on the producer, namely loss of earnings during the period of conversion and the costs of implementing those measures;

Prestrukturiranje in preusmeritev imata dva pomembna finančna vpliva na proizvajalca, izgubo dobička $\mathrm{v}$ času prestrukturiranja namreč in stroške izvajanja teh ukrepov;

The difference between the use of namrec in Slovene texts and that of namely in English has received an early treatment in Klinar $(1994,216)$. The author provides invaluable practical insight with a plethora of translation equivalents, ranging from the ubiquitous namely to several other possible lexical choices, such as that is/was, i.e., for, as, because, the thing is, the reason is, and even a shift in word order to foreground a certain element in the utterance. All the proposed solutions are illustrated by means of a Slovene sentence and its English translation, so the translator is well-served in his/her search for translation options.

\section{Solution?}

The answer to the problem above (and a host of similar ones) will have to come from various sources. Bilingual lexicography, EFL teaching and translator education will each have to provide parts of the puzzle.

\subsection{Better dictionaries}

First of all, a good encoding dictionary will take into account the frequency of a given meaning of a polysemous lexeme in the source language and organize its microstructure accordingly. In such dictionaries, the most frequent meaning is listed first and followed by others with decreasing frequency. This principle has been put into practice since the very beginning of corpus-based lexicography back in the 1980s, when the Collins publishing house led the way with their corpus-driven COBUILD dictionary (Sinclair 1987). Of course, polysemy and divergent 
polysemy in particular deserve special attention: here not only possible translation equivalents should be listed, but also guidelines for the dictionary user as to how and when to pick a certain equivalent. In the case of namreč-namely highly specific contrastive relationship the wide gap between usages in Slovene and English certainly merits a usage note containing some sort of warning or explanation of the systematic difference. In an encoding dictionary, the entry for namrec - in accordance with the above principles - might look something like this:

namreč - (za pojasnjevanje) that is, that was: nekaj časa je to šlo, namreč, ko je bil še doma - for a while it worked, that was while he was still at home; (v vzročni zvezi) for, as, because: Mankoć ima tu rahlo prednost - ima namreč 5 zlatih, 1 srebrno in 2 bronasti kolajn-Mankoč is slightly in front, for he has won 5 gold, 1 silver and 2 bronze medals; (za podrobnejše razlage ali naštevanje) namely: davčna stopnja bo še nižja, namrě̀ 1,91 odstotka vrednosti - tax rate will be even lower, namely 1.91 percent of the value

\subsection{Better teaching}

What can be done in the EFL field? A lot, where lexical topics are concerned. It is understandable and in fact almost universal practice that learners at their early levels are painted a simple picture in terms of lexis, one they can relate to and can use to begin to build their L2 vocabulary. A more detailed and complex rendering of the matter would be counterproductive and only lead to confusion at this primary stage. The potential danger of the boiled-down oversimplified learners' version of the vocabulary is, however, in clinging to it for too long: even advanced students of translation often commit errors that reflect a one-to-one L1-L2 lexical mapping. Unfortunately, things are not that simple and we can only begin to guess at how intricate lexical reality is, let alone an interlingual one. The only question is: when are EFL learners ready to have their idealized lexical picture distorted or even shattered by real-life issues like polysemy, zero derivation, false friends? What is not too early, and not too late? It will ultimately depend on the learner, of course, but certainly no later than at upper intermediate level, i.e. in years 3 and 4 of secondary schooling. Better awareness of the complexity behind words would thus no longer be limited to the lucky few who happen to have that extra knack in foreign languages we often dub talent. Besides grammar and morphology, vocabulary should also be given due weight and more time in secondary school curricula should be devoted to vocabulary-related topics.

\subsection{Translator training}

In short, in translator training contrastive lexicology is the cure. Once alerted to the existence of lexical problems like collocations, paradigmatic meaning relations, (non-)overlapping phraseology patterns etc, students will gradually become more aware of numerous traps and consequently more cautious in both encoding and decoding. Given the overwhelming size of the topic and its complexity, this is bound to be a slow (in fact neverending) process. Frustrating, of course. Rewarding? No doubt. 


\section{Bibliography}

British National Corpus World Edition. 2001. (DVD-ROM). Oxford: Oxford University Press.

Gabrovšek, D. 2005. Words Galore: Aspects of General and Slovenian-English Contrastive Lexicology. Ljubljana: Filozofska fakulteta, Oddelek za anglistiko in amerikanistiko.

Grad, A., and H. Leeming. 1990. Slovene-English Dictionary. 9th reprint. Ljubljana: DZS.

Klinar, S. 1994. Gradivo za vaje iz prevajanja v angleščino. Ljubljana: Filozofska fakulteta.

Mish, F.C., ed. 2003. Merriam-Webster's Collegiate Dictionary. 11th ed. Springfield, MA: Merriam-Webster.

Rundell, M., ed. 2002. Macmillan English Dictionary. Oxford: Macmillan Education.

Slovenska akademija znanosti in umetnosti, ed. 1970-91. Slovar slovenskega knjižnega jezika. Ljubljana: DZS. CD-ROM, 1998.

Sinclair, J., ed. 1987. Collins COBUILD English Language Dictionary. London and Glasgow: Collins Publishers.

Sinclair, J., ed. 2006. Collins COBUILD Advanced Learner's English Dictionary. Glasgow: HarperCollins Publishers.

Summers, D., ed. 2006. Longman Exams Coach. Harlow, Essex: Pearson Education / Longman.

Walter, E., ed. 2005. Cambridge Advanced Learner's Dictionary. 2nd ed. Cambridge: Cambridge University Press.

Wehmeier, S., ed. 2005. Oxford Advanced Learner's Dictionary. 7th ed. Oxford: Oxford University Press.

Zaranšek, P., ed. 2006. Mali angleško-slovenski in slovensko-angleški slovar. Ljubljana: DZS.

\section{Internet sources}

Elan. http://nl2.ijs.si//index-bi.html (accessed 17 December 2007)

Evrokorpus. http://evrokorpus.gov.si/ (accessed 17 December 2007)

FidaPLUS. http://www.fidaplus.net/ (accessed 17 December 2007)

Trans. http://nl2.ijs.si//index-bi.html (accessed 17 December 2007)

Nova beseda. http://bos.zrc-sazu.si/a_beseda.html (accessed 17 December 2007)

Collins English Dictionary Online. http://www.collinslanguage.com/ (accessed 17 December 2007) 